\title{
OS USOS DA DIVERSIDADE
}

\section{Clifford Geertz \\ Institute of Advanced Studies, Princeton University - Estados Unidos}

Resumo: Ao discorrer sobre o "Futuro do Etnocentrismo", este artigo parte da premissa de que a globalização, apesar de ter - em muitos casos - diminuído as diferenças entre povos, não tem amenizado os preconceitos e as formas de discriminação que ocorrem em nome dessas diferenças. Ele resgata a importância do antropólogo neste cenário lembrando que a diversidade cultural faz parte da sociedade complexa, remetendo-se não apenas a grupos étnicos ou nacionais bem delimitados, mas também a diferenças de geração, gênero, sexo e classe, entre outros. Neste contexto, a tolerância passiva de modos distantes de vida assim como a aceitação pragmática de nosso próprio paroquialismo são atitudes não somente intelectualmente desonestas mas também moralmente repreensíveis. É no encontro incômodo de subjetividades variantes na sua própria sociedade que o antropólogo define seu lugar.

Palavras-chave: alteridade, diversidade cultural, etnocentrismo, teoria antropológica.

Abstract: Addressing "The Future of Ethnocentrism", this article starts from the premiss that, although globalization may have, in many cases, diminished the differences which separate peoples, the prejudice and forms of discrimination which accompany these differences have not diminished. Furthermore, cultural diversity, in this scenario, is not confined to clearly delimited ethnic and national groups but includes other factors such as gender, generation, sex and class. In such a context, the pragmatic acceptation of one's own parochialism or even the passive tolerance of distant modes of life are attitudes which are not only intellectually dishonest but morally reprehensible. It is in the uncomfortable encounters of variant subjectivities within his own society that the anthropologist defines his role.

Keywords: anthropological theory, cultural diversity, ethnocentrism, otherness. 
1

A antropologia, minha froliche Wissenschaft, esteve fatalmente envolvida no decorrer de sua história (longa, se iniciada com Heródoto, ou bastante curta, se com Tylor) com a ampla variedade de maneiras pelas quais homens e mulheres tentaram viver suas vidas. Em alguns pontos, ela procurou lidar com esta variedade capturando-a nalguma rede universalizante de teoria: estágios evolucionários, idéias ou práticas pan-humanas, ou formas transcendentais (estruturas, arquétipos, gramáticas subterrâneas). Noutros, ela enfatizou particularidade, idiossincrasia, incomensurabilidade - reis e repolhos. Mas, recentemente, viu-se diante de algo novo: a possibilidade da variedade estar se diluindo num espectro mais pálido e estreito. Nós podemos estar diante de um mundo onde simplesmente não há mais caçadores de cabeça, matrilinearistas, ou quem faça a previsão do tempo com os bofes de um porco. Haverá diferenças, com certeza - os franceses jamais comerão manteiga com sal. Mas os bons velhos tempos de queima de viúvas e canibalismo foram-se para sempre.

Em si mesmo, enquanto questão profissional, este processo de diluição do contraste social (supondo-o verdadeiro) talvez não seja tão perturbador. Os antropólogos terão simplesmente de aprender a fazer alguma coisa com diferenças mais sutis, e seus escritos podem tornar-se mais argutos, embora menos espetaculares. Mas ele levanta uma questão maior, moral, estética e cognitiva ao mesmo tempo, que é muito mais problemática e está no centro da discussão atual sobre como os valores hão de ser justificados: que chamarei, para ter um título fácil de lembrar, O Futuro do Etnocentrismo.

Retomarei em breve a essas discussões mais genéricas, pois a elas dirige-se o grosso da minha preocupação; mas quero começar a abordagem do problema apresentando um argumento, que considero incomum e mais do que um pouco desconcertante, que o antropólogo francês Claude Lévi-Strauss desenvolve no início de sua recente coleção de ensaios, contenciosamente intitulada (contenciosamente, pelo menos, para um antropólogo) O Olhar Distanciado - Le regard éloigné. ${ }^{1}$

1 Claude Lévi-Strauss (1986), O Olhar Distanciado: todas as citações na seção 2 deste ensaio, com apenas algumas grafias adaptadas ao português do Brasil, são da referida edição.

Horizontes Antropológicos, Porto Alegre, ano 5, n. 10, p. 13-34, maio 1999 
2

Em primeiro lugar o argumento de Lévi-Strauss surgiu como resposta ao convite da UNESCO para pronunciar a conferência inaugural do Ano Internacional de Combate ao Racismo e à Discriminação Racial, que, caso vocês tenham perdido, foi 1971. "Fui escolhido", ele escreve,

porque, vinte anos antes, eu tinha escrito um texto, Raça e História, também por encomenda da UNESCO [no qual] eu enunciava [...] certas verdades primeiras, depressa me tendo apercebido de que apenas esperavam de mim a sua repetição. Ora, já nessa época, para servir as instituições internacionais a que, mais do que hoje em dia, me sentia obrigado a dar crédito, acabei por forçar um pouco a nota na conclusão de Raça e História. Talvez devido à idade, certamente as reflexões suscitadas pelo espetáculo do mundo, repugnava-me agora essa complacência e convenci-me de que, para ser útil à UNESCO e poder cumprir honestamente a missão que me era confiada, me deveria exprimir com a máxima franqueza. (p. 14).

Como de costume, isso acabou não sendo uma boa idéia, e o que se seguiu foi de certo modo uma farsa. Funcionários da UNESCO ficaram aborrecidos por "eu ter tocado num catecismo [cuja aceitação] lhes tinha valido a passagem de um emprego modesto em qualquer país em vias de desenvolvimento para o lugar, santificado, de funcionários de uma instituição internacional” (p. 14). O então Diretor Geral da UNESCO, outro francês resoluto, inesperadamente interveio para reduzir o tempo que Lévi-Strauss tinha para falar e assim forçá-lo a fazer os cortes de "melhoramento" que lhe haviam sido sugeridos. Lévi-Strauss, incorrigible, leu o seu texto inteiro, aparentemente em alta velocidade, no tempo que ainda restava.

À parte tudo isso, um dia normal na ONU, o problema com a fala de Lévi-Strauss foi que nela "insurgi-me contra o abuso de linguagem com que se confunde cada vez mais o racismo... com atitudes normais, mesmo legítimas, e, em qualquer caso, inevitáveis" (p. 15) - isto é, embora ele assim não o denomine, etnocentrismo.

Etnocentrismo, argumenta Lévi-Strauss naquele artigo, "Raça e Cultura", e, um tanto mais tecnicamente, em outro, "O Antropólogo e a Condição 
Humana", escrito cerca de uma década mais tarde, não apenas não é uma coisa ruim em si mesma, mas, desde que não acabe fora de controle, é uma coisa bastante boa. A lealdade a um certo conjunto de valores torna as pessoas inevitavelmente "parcial ou totalmente insensíveis a outros valores" (p. 15) aos quais, outras pessoas, igualmente paroquiais, são igualmente leais. "Ele não tem culpa alguma de que se ponha uma maneira de viver ou de pensar acima de todas as outras, nem de que se sinta pouca atração (por outros valores)". Esta "incomunicabilidade relativa" não autoriza ninguém a oprimir ou destruir os valores rejeitados ou aqueles que os sustentam. Mas, afora isto, "ela nada tem de revoltante".

Pode mesmo representar o preço a pagar para que os sistemas de valores de cada família espiritual ou de cada comunidade se conservem, e encontrem no seu próprio fundo as fontes necessárias à sua renovação. Se... existe entre as sociedades humanas um certo optimum de diversidade para além do qual elas não poderiam existir, mas abaixo do qual elas não podem também descer sem perigo, deve reconhecer-se que esta diversidade resulta em grande parte do desejo de cada cultura de se opor àquelas que a rodeiam, de se distinguir delas, numa palavra, de ser ela mesma; elas não se ignoram, apropriam-se de coisas umas das outras sempre que há ocasião, mas, para que não pereçam, é preciso que, sob outras relações, persista entre elas uma certa impermeabilidade. (p. 15-16).

Não é portanto apenas uma ilusão pensar que a humanidade possa se livrar totalmente do etnocentrismo "nem que deva desejar-se que o faça" (p. 16); não seria bom que o fizesse. Uma tal "liberdade" levaria a um mundo “em que as culturas, presas por uma paixão recíproca, já não aspirariam a mais do que a celebrar-se mutuamente, numa confusão em que cada uma perderia o atrativo que poderia ter para as outras, e as suas próprias razões de existir" (p. 16).

A distância oferece, se não encanto, pelo menos indiferença, e, portanto, integridade. No passado, quando as chamadas culturas primitivas se viam apenas muito marginalmente envolvidas umas com as outras - chamando os seus próprios membros de "Os Verdadeiros", "Os Bons", ou simplesmente "Os Seres Humanos" e os outros, que estavam do outro lado do rio, de "macacos da terra" ou "ovos de piolho", isto é, não, ou não completamente, humanos - a 
integridade cultural era prontamente mantida. Uma "profunda indiferença pelas culturas alheias era... uma garantia de poderem existir à sua vontade e do seu lado" (p. 26). Agora, quando está claro que este não é mais o caso, e todo mundo, cada vez mais apertado num pequeno planeta, está profundamente interessado em todo mundo e no que todo mundo faz, a possibilidade de perder tal integridade, por causa da perda de tal indiferença, paira no ar. Pode ser que o etnocentrismo nunca desapareça completamente, sendo "inerente à nossa espécie" (p. 16), mas ele pode se tomar perigosamente fraco, deixando-nos à mercê de um tipo de entropia moral:

É inegável que nos embalamos no sonho de que a igualdade e a fraternidade reinarão um dia entre os homens, sem que a sua diversidade seja comprometida. Mas se a humanidade não se resignar a tornar-se a consumidora estéril dos únicos valores que soube criar no passado, unicamente capaz de dar à luz obras bastardas, invenções grosseiras e pueris, [então] ela deverá reaprender que toda a verdadeira criação implica uma certa surdez ao apelo de outros valores, podendo ir até à sua recusa, senão mesmo até à sua negação. Porque não se pode, ao mesmo tempo, fundir-se no gozo do outro, identificar-se com ele, e manter-se indiferente. Plenamente alcançada, a comunicação integral com o outro condena, mais tarde ou mais cedo, a originalidade da sua criação e da minha. As grandes épocas criadoras foram aquelas em que a comunicação se tornara suficiente para que parceiros afastados se estimulassem, sem que no entanto fosse excessivamente frequente e rápida para que os obstáculos, tão indispensáveis entre os indivíduos como entre os grupos, se reduzissem, a ponto de trocas demasiado fáceis virem igualar e confundir a sua diversidade. (p. 48).

Não obstante o que se pensar disso tudo, ou por mais surpresa que se tenha ouvindo-o de um antropólogo, não há dúvida de que a nota soa contemporânea. As tentações da "surdez ao apelo de outros valores" e da abordagem tipo relaxe-e-goze de quem se aprisiona na sua própria tradição cultural são cada vez mais celebradas no pensamento social recente. Sem poderem abraçar nem o relativismo nem o absolutismo - o primeiro porque incapacita o juízo e o segundo porque retira-o da história - nossos filósofos, historiadores e cientistas sociais se voltam para o tipo de imperméabilité nós-somos-nós e eles-são-eles que Lévi-Strauss recomenda. Visto tanto como arrogância facilitada, preconceito justificado, ou como a esplêndida honestidade eu-sou-assim de Flannery 
O'Connor recomendando, "em Roma, faz como farias em Milledgeville", o fato é que isso coloca claramente a questão d'O Futuro do Etnocentrismo - e da diversidade cultural - sob uma nova luz. Será que o afastamento, distanciar-se até outro lugar, O Olhar Distanciado, é realmente o meio de fugir da tolerância desesperada do cosmopolitanismo à la UNESCO? A alternativa para a entropia moral é o narcisismo moral?

São múltiplas as forças que vêm promovendo uma maior aceitação do autocentrismo cultural nos últimos vinte e cinco ou trinta anos. Há aquelas questões de "estado do mundo" às quais Lévi-Strauss alude, mormente o fracasso da maioria dos países de Terceiro Mundo em se manter à altura das esperanças de mil flores presentes para eles logo antes e logo depois de suas lutas de independência. Amin, Bokassa, Pol Pot e Khomeini nos extremos, e Marcos, Mobuto, Sukarno e a Sra. Gandhi com menos extravagância, emprestaram um certo arrepio à noção de haver mundos noutros lugares comparado aos quais o nosso está sem dúvida doente. Há o repetido desmascaramento das utopias marxistas - União Soviética, China, Cuba, Vietnam. E há o enfraquecimento do pessimismo do Declínio do Ocidente induzido por guerra mundial, depressão mundial, e a perda do império. Mas há também, e acho não menos importante, o aumento da conscientização de que o consenso universal-transnacional, transcultural, até transclasse - sobre questões normativas não virá num futuro próximo. Todo mundo - sikhs, socialistas, positivistas, irlandeses - não se voltará para a mesma opinião sobre o que é e o que não é decente, o que é e o que não é justo, o que é e o que não é lindo, o que é e o que não é razoável; não em breve, talvez nunca.

Se abandonamos (e é claro que nem todo mundo, talvez nem mesmo a maioria, o fez) a idéia de que o mundo está indo em direção a um acordo essencial sobre questões fundamentais, ou mesmo, como no caso de LéviStrauss, que deveria, então cresce naturalmente o encanto do etnocentrismo tipo relaxe-e-goze. Se os nossos valores não podem ser desembaraçados de nossa história e nossas instituições, e nem os de ninguém mais das deles, aí então parece que só resta fazer como Emerson, andar com os nossos próprios 
pés e falar com a nossa própria voz. "Espero sugerir", escreve Richard Rorty num artigo recente (maravilhosamente intitulado 'Liberalismo Burguês Pósmodernista'), "como [nós liberais burgueses pós-modernistas] podemos convencer nossa sociedade de que lealdade a si mesma é lealdade suficiente... que ela precisa ser responsável apenas por suas próprias tradições..." (Rorty, 1983, p. 595). ${ }^{2}$ Aquilo que um antropólogo em busca das "leis consistentes que sublinham a diversidade observável de crenças e instituições" (LéviStrauss, 1986, p. 55) atinge pelo lado do racionalismo e da alta ciência, um filósofo, convencido de que "não há 'fundamento' para [as nossas] lealdades e convicções afora o fato de que as crenças, desejos e emoções que as amparam se sobrepõem aos sentimentos de muitos outros membros do grupo com o qual nos identificamos para fins de deliberação moral e política...", atinge pelo lado do pragmatismo e da ética da prudência (Rorty, 1983, p. 586). A semelhança é até maior apesar dos pontos de partida muito diferentes desses dois sábios (kantianismo sem um sujeito transcendente, hegelianismo sem um espírito absoluto), e dos fins mais diferentes ainda para os quais eles se inclinam (um mundo bem arrumado de formas transponíveis, outro desarranjado de discursos coincidentes), porque Rorty, também, considera as distinções insidiosas entre grupos não apenas naturais mas essenciais ao raciocínio moral:

[O] análogo hegeliano naturalizado da "dignidade humana intrínseca" (kantiana) é a dignidade comparativa de um grupo com o qual uma pessoa se identifica. As nações, igrejas ou movimentos são, deste ponto de vista, exemplos históricos iluminadores não porque reflitam raios emanados de uma força maior, mas por causa dos efeitos de contraste $\sim$ comparação com comunidades piores. As pessoas têm dignidade não por causa de uma luminescência interior, mas por participarem desses efeitos de contraste. É um corolário deste ponto de vista que a justificação moral das instituições e práticas de um grupo - da burguesia contemporânea, por exemplo - é principalmente uma questão de narrativas históricas (inclusive cenários sobre o que é provável que aconteça em certas contingências futuras) em vez de metanarrativas filosóficas. O principal suporte para a historiografia não é a filosofia e sim as artes, que servem para desenvolver e modificar a auto-imagem de um grupo, por exemplo, glorificando os seus

2 Referência em português: Richard Rorty (1997, p. 266). 
heróis, diabolizando seus inimigos, construindo diálogos entre seus membros e refocalizando sua atenção. (Rorty, 1983, p. 586-587).

Agora, como membro dessas duas tradições intelectuais, do estudo científico da diversidade cultural por profissão e do liberalismo burguês pós-moderno por inclinação, meu ponto de vista pessoal, para chegar ao assunto, é que uma rendição fácil aos confortos de simplesmente sermos nós mesmos, cultivando ouvidos moucos e maximizando a gratidão por não ter nascido vândalo ou ik, será fatal para ambas. Uma antropologia com tanto medo de destruir a criatividade e a integridade cultural, nossa e de todos os outros, pelo fato de se aproximar das outras pessoas, envolvendo-as, procurando compreender sua condição imediata e suas diferenças, está fadada a morrer de uma inanição que nenhuma manipulação de conjuntos de dados objetivizados pode compensar. Qualquer filosofia moral tão medrosa de se embaraçar em relativismo idiota ou dogmatismo transcendental que o melhor que pode pensar em fazer com outras maneiras de enfrentar a vida é fazê-las parecer pior do que a nossa própria está fadada meramente a conduzir (como disse alguém dos escritos de V. S. Naipaul, talvez nosso maior adepto da construção de tais "efeitos de contraste") no sentido de tornar o mundo seguro para a condescendência. Tentar salvar duas disciplinas de si mesmas ao mesmo tempo pode parecer arrogante. Mas quando alguém possui dupla cidadania, tem obrigações dobradas.

4

Não obstante suas diferentes posturas e diferentes causas (e confesso que estou muito mais próximo do populismo desordenado de Rorty do que do mandarinismo preciosista de Lévi-Strauss - o que talvez não passe de um viés cultural da minha parte), essas duas versões de para-cada-qual-a-sua moralidade residem, pelo menos em parte, numa idéia comum de diversidade cultural: ou seja, que é importante porque nos dá, para usar a fórmula de Bernard Williams, alternativas a nós em vez de alternativas para nós. Outros valores, crenças e modos de levar a vida são vistos como valores que sustentaríamos, crenças que teríamos e modos como levaríamos a vida se houvéssemos nascido em época e lugar diversos de quando e onde realmente nascemos. 
E assim, de fato, teria sido. Mas uma tal idéia parece dar muito mais e muito menos importância do que deveria ao fato da diversidade cultural. Muito mais, porque ela sugere que ter tido uma vida diferente do que realmente se teve é uma opção prática sobre a qual de alguma forma a pessoa tem que se decidir (eu deveria ter sido um bororó? é ou não é sorte minha não ter sido um hitita?); muito menos, porque ela obscurece o poder de tal diversidade, quando invocada pessoalmente, de transformar nossa percepção de o que significa para um ser humano, bororó, hitita, estruturalista, ou liberal burguês pós-moderno, acreditar, dar valor, ou prosseguir: qual é a sensação, como observou Arthur Danto (1984, p. 646-647), fazendo eco à famosa pergunta de Thomas Nagel sobre o morcego, "de pensar que o mundo é plano, que eu pareço irresistível nos meus trajes Poiret, que o reverendo Jim Jones me teria salvado pelo seu amor, que os animais não têm sentimento ou que as flores têm - ou que a onda é ser punk." O problema com o etnocentrismo não é que ele nos comprometa com os nossos próprios compromissos. Nós somos, por definição, tão comprometidos, quanto somos com ter as nossas próprias dores de cabeça. O problema com o etnocentrismo é que nos impede de descobrir em que tipo de ângulo, como o Cavafy de Foster, nós nos postamos em relação ao mundo; que tipo de morcego realmente somos.

Esta idéia - de que os enigmas postos pelo fato da diversidade cultural têm mais a ver com a nossa capacidade de penetrar às apalpadelas nas sensibilidades alienígenas, nos modos de pensar (rock punk e batas Poiret) que não possuímos, e nem provavelmente vamos possuir, do que com a nossa capacidade de aceitar ou deixar de preferir nossas próprias preferências - tem uma série de implicações de mau agouro para a abordagem de coisas culturais baseada em nós-somos-nós e eles-são-eles. A primeira delas, talvez a mais importante, é que tais enigmas brotam não simplesmente nas fronteiras de nossa sociedade, como seria de esperar sob uma tal abordagem, mas, por assim dizer, nas fronteiras de nós mesmos. O sentimento de ser estrangeiro não começa à beira d'água mas à flor da pele. O tipo de idéia que tanto os antropólogos desde Malinowski como os filósofos desde Wittgenstein tendem a alimentar, de que, digamos, shiitas, sendo outro, dão um problema, mas torcedores de futebol, sendo parte de nós, não dão, ou pelo menos não do mesmo tipo, e simplesmente errado. O mundo social não se divide nas suas articulações em 
transparentes "nós" com quem podemos ter empada, por mais que diferamos com eles, e enigmáticos "eles", com quem não podemos, por mais que defendamos até a morte o direito deles de diferir de nós. Os wogs começam muito antes de Calais.

Tanto a antropologia recente do tipo Do Ponto de Vista do Nativo (que eu pratico) como a filosofia recente do tipo Formas de Vida (que eu endosso) foram levadas a conspirar, ou a parecer conspirar, para obscurecer este fato através de uma má aplicação crônica de sua idéia mais poderosa e mais importante: a idéia de que o significado é socialmente construído.

A percepção de que significação, na forma de sinais interpretáveis -sons, imagens, sentidos, artefatos, gestos - passa a existir apenas no bojo dos jogos de linguagem, comunidades de discurso, sistemas intersubjetivos de referência, modos de construção de mundo; de que ele surge dentro do quadro da interação social concreta na qual algo é um algo para um "você" e um "eu", e não numa gruta secreta qualquer da cabeça; e de que ele é histórico de ponta a ponta, forjado no fluxo dos eventos, é interpretada com a implicação de que as comunidades humanas são, ou deveriam ser, mônadas semânticas,

Wog, termo pejorativo com que um inglês se refere aos franceses; e Calais, cidade portuária francesa no Canal da Mancha, ponto de desembarque usual na França para quem vem da Inglaterra por via marítima, quase sem aberturas (o que, na minha opinião, nem Malinowski nem Wittgenstein, e nem, por sinal, Kuhn ou Foucault quiseram dar a entender). Nós somos, diz Lévi-Strauss, passageiros nos trens que são nossas culturas, cada qual movendo nos seus próprios trilhos, no seu próprio ritmo e na sua própria direção. Os trens que rolam lado a lado, em direções semelhantes e velocidades não muito diferentes das nossas, são pelo menos razoavelmente visíveis para nós quando olhamos para fora de nossas cabines. Mas os trens em trilhos oblíquos ou paralelos rolando numa direção oposta não o são.

Dele não recebemos senão uma imagem confusa e depressa desaparecida, dificilmente identificável, as mais das vezes reduzida a uma mancha momentânea do nosso campo visual, que não nos dá qualquer informação sobre o próprio acontecimento e que só nos irrita, porque interrompe a contemplação plácida da paisagem que serve de pano de fundo aos nossos devaneios. (Lévi-Strauss, 1986, p. 30-31). 
Rorty é mais cauteloso e menos poético, e me parece menos interessado nos trens de outras pessoas, de tão preocupado que está com o destino do seu próprio trem, mas ele fala de uma "sobreposição" mais ou menos acidental de sistemas de crença entre comunidades "norte-americanas burguesas ricas" e outras "com as quais precisamos falar" para propiciar "qualquer conversação entre nações que ainda seja possível" (Rorty, 1983, p. 588). O enraizamento de sentido, pensamento e juízo numa forma de vida - que de fato é o único lugar, no meu ponto de vista e no de Rorty, onde eles podem se enraizar- é tomado na acepção de que os limites do meu mundo são os limites de minha linguagem, o que não é exatamente o que o homem disse.

O que ele disse, é claro, foi que os limites da minha linguagem são os limites do meu mundo, o que não significa que o alcance de nossas mentes, daquilo que dizemos, pensamos, apreciamos, e julgamos, esteja confinado dentro das fronteiras da nossa sociedade, do nosso país, nossa classe ou nosso tempo, mas sim que o alcance de nossas mentes, a série de sinais que conseguimos de alguma forma interpretar, é o que define o espaço intelectual, emocional e moral dentro do qual vivemos. Quanto maior isso for, quanto maior pudermos torná-lo através dum esforço para compreender o reverendo Jim Jones ou quem crê que a terra é plana (ou os iks ou os vândalos), como é ser eles, mais claros tomamo-nos para nós mesmos, tanto em termos do que vemos nos outros e parece remoto quanto do que vemos e parece familiar, do que atrai e do que repele, do que é sensato e do que é pura loucura; opostos que não se alinham de nenhuma maneira simples, pois há certas coisas bem atraentes a respeito de morcegos, e coisas bem repugnantes a respeito de etnógrafos.

São, como diz Danto (1984, p. 647) no artigo que citei há pouco, "as diferenças entre eu e aqueles que pensam diferentemente de mim - o que vale dizer todos, e não simplesmente aqueles segregados por diferenças de gerações, sexo, nacionalidade, seita, e até mesmo raça - que definem as fronteiras reais do self'. São as assimetrias, como ele também diz, ou quase, entre o que nós acreditamos ou sentimos e o que os outros crêem e sentem, que torna possível localizar aonde nós estamos agora no mundo, qual é a sensação de aí estar, e onde podemos querer ou não querer ir. Obscurecer essas diferenças e essas assimetrias relegando-as ao campo das diferenças reprimíveis ou ignoráveis, mera dessemelhança, que é o que o etnocentrismo faz e é programado 
para fazer (o universalismo da UNESCO as obscurece - Lévi-Strauss está certíssimo quanto a isso - ao negar totalmente a sua realidade), significa nos isolar de tal conhecimento e tal possibilidade: a possibilidade de mudar, no mais amplo e literal dos sentidos, nossa mentalidade.

5

A história de qualquer povo separadamente e de todos os povos juntos, e sem dúvida de cada pessoa individualmente, é a história da mudança de mentalidade, vagarosa em geral, mais rápida às vezes; ou se o tom idealista disso perturbar você (não deveria, não é idealista, e não nega nem as pressões naturais do fato, nem os limites materiais da vontade), de sistemas de signos, formas simbólicas, tradições culturais. Tais mudanças não foram necessariamente para melhor, quiçá nem mesmo normalmente. Elas tampouco levaram a uma convergência de pontos de vista, mas sim a uma mistura deles. Aquilo que, voltando à sua bendita Idade neolítica, foi algo bastante semelhante ao mundo de sociedades integrais em comunicação distante imaginado por LéviStrauss, tornou-se algo mais parecido com o mundo pós-moderno de Danto, de sensibilidades conflitantes em contato inevitável. Assim como a nostalgia, a diversidade não é mais como a de antigamente; e o confinamento de vidas em vagões de trem separados a fim de produzir renovação cultural ou o seu espaçamento por efeitos de contraste a fim de liberar energias morais são sonhos românticos, não isentos de perigo.

A tendência geral que observei ao iniciar este artigo, do espectro cultural tornar-se mais pálido e mais contínuo sem tomar-se menos discriminatório (de fato, ele está se tornando provavelmente mais discriminatório na medida em que as formas simbólicas se separam e proliferam), altera não apenas sua relação com o argumento moral mas o próprio caráter de tal argumento. Nós nos habituamos à idéia de que os conceitos científicos mudam com as mudanças nos tipos de questões com que se ocupam os cientistas - que não há necessidade de cálculo para determinar a velocidade de uma carruagem ou de energias quânticas para explicar o movimento de um pêndulo. Mas estamos bem menos conscientes de que a mesma coisa é verdadeira para os instrumentos especulativos (para tomar emprestado de I. A. Richard um velho termo que 
merece ser ressuscitado) do raciocínio moral. As ideias que bastam para as magníficas diferenças de Lévi-Strauss não bastam para as assimetrias inquietantes de Danto; e é com estas que nos defrontamos cada vez mais.

Mais concretamente, questões morais advindas da diversidade cultural (que não são, nem de longe, todas as questões morais que há) que costumavam surgir, se é que surgiam, principalmente entre sociedades - "costumes contrários à razão e à moralidade" e esse tipo de coisa do qual o imperialismo se alimentava - agora surgem cada vez mais dentro delas. A coincidência de fronteiras sociais e culturais está cada vez menos aproximada - há japoneses no Brasil, turcos na Alemanha, e a índia Ocidental encontra o Oriente nas ruas de Birmingham - um processo de embaralhamento que vem claramente de longa data (Bélgica, Canadá, Líbano, África do Sul - e a Roma de César não era assim tão homogênea), mas que já está, hoje em dia, alcançando proporções extremas e quase universais. Já se foi o tempo em que a cidade americana era o principal modelo de fragmentação cultural e agitação étnica; a Paris dos nos ancêtres les gaulois está se tornando tão poliglota, e tão policrômica, quanto Manhanttan, e pode vir a ter um prefeito asiático (é o que temem, em todo caso, muitos dos les gaulois) antes de Nova Iorque ter um prefeito hispânico.

Este crescimento no interior do corpo social, dentro dos limites de um "nós", de prementes questões morais centradas na diversidade cultural, e as implicações que isto tem para nosso problema geral, "o futuro do etnocentrismo", pode se tornar talvez bem mais vívido através de um exemplo; não um exemplo inventado, de ficção científica, sobre água nos antimundos ou pessoas cujas memórias intercambiam-se durante o sono, que filósofos passaram recentemente a apreciar com certo exagero, mas um exemplo real, ou pelo menos apresentado como verdadeiro pelo antropólogo que contou-me a história: O Caso do índio Bêbado e O Aparelho de Diálise.

O caso é simples, por mais enrolada que seja sua resolução. A enorme carência, por causa de seu alto custo, de rins artificiais para diálise, gerou, muito naturalmente, alguns anos atrás, um processo de fila por parte de pacientes que precisavam ter acesso a tais aparelhos para fazer diálise, num serviço de saúde pública no sudoeste dos Estados Unidos dirigido, também muito naturalmente, por médicos jovens e idealistas formados em importantes universidades, 
principalmente do nordeste. Para o tratamento surtir efeito, pelo menos a longo prazo, é necessária uma estrita disciplina da parte dos pacientes, quanto à dieta e a outras questões. Tratando-se de uma empresa pública, com regimento antidiscriminatório, e em todo caso, como eu digo, moralmente motivada, a fila foi organizada não em termos de quem podia pagar, mas em termos da gravidade dos casos e da ordem de inscrição, política que levou, com as costumeiras distorções de lógica prática, ao problema do índio bêbado.

O índio, depois de ganhar acesso ao raro aparelho, recusou-se, para grande consternação dos médicos, a parar, ou mesmo a controlar, o seu consumo de álcool, que era prodigioso. Sua postura, dentro de um princípio semelhante àquele de Flannery O'Connor que mencionei anteriormente, de continuar sendo você mesmo a despeito de tudo que os outros possam querer fazer de você, era a seguinte: eu sou mesmo um índio bêbado, eu sou assim há muito tempo, e eu pretendo continuar sendo um índio bêbado enquanto puderem me manter vivo, me enganchando nessa porcaria de máquina de vocês. Os doutores, com seus valores muito diferentes, consideraram que o índio estava bloqueando o acesso de outras pessoas da fila, em situação não menos desesperadora, ao aparelho de diálise; pessoas que poderiam, na opinião deles, aproveitar melhor os benefícios do tratamento - digamos, um tipo jovem, de classe média, bastante parecido com eles próprios, destinado a cursar a universidade e, quem sabe, a faculdade de medicina. Como o índio já estava usando o aparelho no momento em que o problema foi identificado eles não tiveram coragem (nem, eu suponho, teria-lhes sido dada permissão) de desligá-lo; mas ficaram profundamente contrariados - pelo menos tão contrariados quanto o índio, que tinha disciplina suficiente para chegar na hora marcada para todas as sessões, ficou firme em sua decisão - e teriam com certeza arranjado alguma razão, ostensivamente médica, para mudá-lo de lugar na fila se tivessem notado a tempo o que estava por vir. O índio continuou no aparelho e os médicos contrariados, durante vários anos, até que, orgulhoso, como eu o imagino, agradecido (se bem que não aos médicos) por ter tido um prolongamento na vida para beber, e sem qualquer desculpa, ele morreu.

Agora, o ponto desta fabulazinha em tempo real não é mostrar até onde vai a insensibilidade dos doutores (eles não foram insensíveis, e tinham suas razões), ou quão à deriva ficaram os índios (ele não estava à deriva, ele sabia 
exatamente aonde estava); nem sugerir que os valores dos médicos (isto é, mais ou menos, os nossos), ou os do índio (isto é, mais ou menos, não os nossos), ou algum julgamento entre as partes, tirado da filosofia ou antropologia e sentenciado por um dos hercúleos juízes de Ronald Dworkin, deveriam prevalecer. Foi um caso duro e terminou de forma dura; mas eu não vejo como mais etnocentrismo, mais relativismo, ou mais neutralidade poderia ter melhorado as coisas (embora mais imaginação talvez pudesse). O ponto da fábula - não estou certo de que ela tenha uma moral propriamente dita - é que é esse tipo de coisa, não a tribo distante, dobrada sobre si mesma em coerente diferença (os azande ou os ik que fascinam os filósofos apenas um pouco menos do que as fantasias de ficção científica, talvez porque eles podem fazer as vezes de marcianos sublunares e ser vistos como tal), que melhor representa, ainda que com uma pitada de melodrama, a forma geral que o conflito de valores que emerge da diversidade cultural toma hoje em dia.

Neste caso os antagonistas, se é que podemos chamá-los assim, não eram representativos de totalidades sociais isoladas encontrando-se perigosamente à beira de suas crenças. índios mantendo o destino à distância com álcool fazem parte da América contemporânea tanto quanto médicos corrigindo-o com máquinas. (Quem quiser saber exatamente como, pelo menos no que diz respeito aos índios - acho que sobre médicos vocês já sabem - pode ler a eletrizante novela de James Welch, Winter in the Blood, onde surgem efeitos de contraste fora do comum.) Se houve alguma falha aqui, e, justiça seja feita, é difícil mostrar o tamanho exato dela à distância, foi a falta de compreensão, por ambos os lados, de como era estar do outro, e, logo, como era estar do seu próprio lado. Ninguém, ao que parece, aprendeu grande coisa sobre si mesmo ou quem quer que seja neste episódio, e nada, além das banalidades de desgosto e amargura, sobre o caráter do encontro que tiveram. Não é a incapacidade das pessoas envolvidas de abandonar suas convicções e adotar o ponto de vista de outrem que torna esta pequena fábula tão profundamente deprimente. Nem tampouco o fato de lhes faltar uma regra moral não-corporativa - O Bem Maior ou O Princípio da Diferença (que, na verdade, parece que daria aqui resultados diversos) - à qual recorrer. É a incapacidade delas até mesmo de conceber, em meio aos mistérios da diferença, como é possível contornar uma assimetria moral absolutamente genuína. A coisa toda aconteceu no escuro. 
O que tende a acontecer no escuro - as únicas coisas que um conceito de dignidade humana tipo "uma certa surdez aos apelos de outros valores" ou uma "comparação com comunidades piores" parece permitir -, ou é o uso da força para impor os valores dos que possuem a força; uma vácua tolerância que, comprometida com nada, nada muda; ou, como neste caso, onde a força não está disponível e a tolerância é desnecessária, uma trôpega chegada a um ambíguo fim.

O fato é que há, sem dúvida, circunstâncias onde as alternativas práticas realmente existem. Parece que não há muito o que fazer no caso do reverendo Jones, depois de ele desembestar em busca de seus objetivos, a não ser pará-lo fisicamente antes dele distribuir o refresco. Se as pessoas acham que o rock punk é que está na onda, aí, pelo menos enquanto não o tocarem no metrô, o ouvido é delas e o funeral também. E é difícil (alguns malucos são mais malucos do que outros) saber exatamente como se deve lidar com alguém que afirma que as flores possuem sentidos e os animais não os possuem. O paternalismo, a indiferença, até mesmo a petulância não são sempre atitudes inúteis de se tomar diante da diferença de valores, inclusive as de maior consequência do que estas. O problema é saber quando elas são úteis e a diversidade pode ser deixada com segurança nas mãos dos seus connoisseurs, e quando, como me parece ser cada vez mais frequentemente o caso, elas não são e ela não pode, e é preciso algo mais: uma passagem imaginativa para (e reconhecimento de) uma maneira "outra" de pensar.

Na nossa sociedade, o connoisseur por excelência das maneiras "outras" de pensar tem sido o etnógrafo (o historiador também, até um certo ponto, e dum modo diverso o romancista, mas eu quero voltar à minha própria reserva) dramatizando a estranheza, exaltando a diversidade, e respirando a profusão de pontos de vista. Sejam quais forem as diferenças em método ou teoria que nos separam, em algo nos iguala: profissionalmente temos obsessão pelos mundos distantes e por torná-los compreensíveis primeiro para nós mesmos e depois, através de esquemas conceituais não muito diferentes dos dos historiadores e de esquemas literários não muito diferentes dos dos romancistas, para nossos leitores. E enquanto esses mundos estiverem realmente alhures, 
onde Malinowski encontrou-os e Lévi-Strauss os relembra, isto foi, apesar de bastante difícil como tarefa prática, uma tarefa analítica relativamente sem problemas. Nós podíamos pensar sobre os "primitivos" ("selvagens", "nativos"...) como pensamos sobre marcianos - como possíveis maneiras de sentir, argumentar, julgar e se comportar, de prosseguir, discontínuas às nossas, alternativas a nós. Agora que aqueles mundos e aquelas maneiras "outras" de pensar não estão em sua maioria realmente alhures, mas são, bem aqui ao lado, alternativas para nós, "lacunas (imediatas) entre eu e aqueles que pensam de forma diferente de mim, um certo reajuste dos nossos hábitos retóricos assim como de nosso sentido de missão parece estar na ordem do dia.

Os usos da diversidade cultural, de seu estudo, sua descrição, análise e compreensão dependem menos de separarmos nós mesmos dos outros e os outros de nós para defesa da integridade do grupo e manutenção da lealdade do grupo do que de definir o terreno a ser percorrido pela razão se as suas modestas recompensas tiverem de ser alcançadas e apreciadas. Esse terreno é desigual, cheio de falhas repentinas e passagens perigosas onde acidentes podem acontecer e acontecem, e cruzá-lo, ou tentar, pouco ou nada faz para torná-lo seguro, nivelado e sem barrancos, mas apenas torna visível seus contornos e fissuras. Se nossos peremptórios doutores e nosso intransigente índio (ou o "rico norte americano" de Rorty e aqueles "com quem precisamos falar") forem se defrontar de uma maneira menos destrutiva (e não há nenhuma certeza - as fissuras são reais - de que eles realmente possam fazer isto) eles têm de explorar o caráter do espaço que os separa.

São eles próprios que têm de fazer isto, afinal; aqui não há substituto para o conhecimento local, nem tampouco para a coragem. Mas mapas e guias ainda podem ser úteis, bem como tabelas, lendas, gravuras, e descrições, até teorias, se eles responderem também ao real. Os usos da etnografia são principalmente ancilares, mas são reais, não obstante; como a compilação de dicionários ou o polimento de lentes, ela é, ou seria, uma disciplina de capacitação. E o que ela capacita, quando o faz, é um contato viável com uma subjetividade variante. Ela coloca alguns nós no meio de alguns eles, e alguns eles no meio de alguns nós, onde todos, como venho dizendo, por maior que seja o seu desconforto, já estão. Ela é a grande inimiga do etnocentrismo, do confinamento de pessoas em planetas culturais onde as únicas idéias que precisam invocar 
são "aquelas em torno daqui", não porque assuma que as pessoas são todas iguais, mas porque sabe quanto elas não o são e como são incapazes, ainda assim, de se desconsiderarem mutuamente. Mesmo que um dia tenha sido possível e mesmo que hoje provoque saudades, a soberania do familiar empobrece a todos; enquanto ela tiver um futuro, na mesma medida, o nosso é tenebroso. Não é que tenhamos de amar um ao outro ou morrer (se for assim - negros e afrikaners, árabes e judeus, tamiles e singaleses - acho que estamos condenados). Temos é de conhecer um ao outro, e viver com este conhecimento, ou acabar como náufragos num mundo beckettiano de solilóquios em colisão.

A tarefa da etnografia, ou uma delas em todo caso, é sem dúvida fornecer, como fazem a história e as artes, narrativas e cenários para refocalizar a nossa atenção; não, no entanto, os que nos tornam aceitáveis para nós mesmos pela representação de outros reunidos dentro de mundos onde não queremos e não podemos chegar, mas os que nos tornam visíveis para nós mesmos pela representação de nós e todos os demais postos no meio de um mundo cheio de estranhezas irremovíveis das quais não podemos nos manter distantes.

Até bem recentemente (a situação agora está mudando, em parte pelo menos por causa do impacto da etnografia, mas principalmente porque o mundo está mudando) a etnografia estava sozinha nisso, pois a história gastava muito do seu tempo confortando a nossa auto-estima e apoiando a nossa impressão de que estávamos chegando a algum lugar pela glorificação de nossos heróis e a diabolização dos nossos inimigos, ou lamentando a grandeza extinta; o comentário social de romancistas era na sua maior parte localizado - uma parte da consciência ocidental segurando um espelho, plano à Trollope ou curvo à Dostoievsky, para a outra; e mesmo a literatura de viagem, que pelo menos tocava em superfícies exóticas (selvas, camelos, bazares, templos) usava-as principalmente para demonstrar a resiliência, em árduas circunstâncias, de virtudes adquiridas - o inglês mantendo-se calmo, o francês racional, o americano inocente. Agora, quando já não está tão sozinha e as estranhezas com que tem de lidar estão ficando mais oblíquas e nebulosas, menos facilmente apartadas como anomalias selvagens - homens que se julgam descendentes de cangurus ou crêem que podem ser assassinados com uma olhadela de viés sua tarefa, de localizar aquelas estranhezas e descrever suas formas, pode ser de certa forma mais difícil; mas é dificilmente menos importante. Imaginar 
diferenças (que não significa inventá-las, é claro, mas torná-las evidentes) continua sendo uma ciência da qual todos nós temos necessidade.

7

Mas meu propósito aqui não é defender as prerrogativas de uma Wissenschaft caseira cuja patente sobre o estudo da diversidade cultural, se um dia ela teve uma, expirou há muito tempo. Meu propósito é sugerir que chegamos a um tal ponto da história moral do mundo (claro, uma história que é tudo menos moral) que somos obrigados a pensar sobre tal diversidade de uma maneira bem diferente da que estamos acostumados. Se for verdade que, ao invés de estarem sendo separados em unidades cercadas e espaços sociais com bordas bem definidas, modos de viver seriamente díspares estão se misturando em áreas mal definidas e espaços sociais de bordas soltas, irregulares e difíceis de localizar, então a questão de como lidar com os quebra-cabeças de julgamento que tais disparidades levantam assume um aspecto bem diferente. Confrontar paisagens e naturezas-mortas é uma coisa; panoramas e colagens é bem outra.

Parece claro por toda parte que nos dias de hoje nós confrontamos essas últimas, que estamos vivendo cada vez mais no meio de uma enorme colagem. Não é apenas no noticiário da noite onde assassinatos na índia, bombardeios no Líbano, golpes na África, e tiroteios na América Central são distribuídos entre desastres locais dificilmente mais legíveis e seguidos por sérias discussões sobre a maneira japonesa de fazer negócios, formas persas de paixão, ou estilos árabes de comerciar. É também uma enorme explosão de tradução, boa, má, e insípida, de e para linguagens - tamil, indonésio, hebreu, e urdu - antes consideradas marginais e recônditas; a migração de cozinhas, costumes, mobílias e decorações (cafetãs em San Francisco, Colonel Sanders em Jogjakarta, tamboretes de bar em Kyoto); o surgimento de temas para gamelão no jazz de avant garde, mitos índios em novelas latinas, imagens de revistas em pintura africana. Mas principalmente é que - a chance é quase a mesma - a pessoa que encontramos na feira pode vir tanto da Coréia como de Iowa; no correio, da Algéria como de Au vergne; no banco, de Bombaim como de Liverpool. Nem mesmo cenários rurais, onde a semelhança tende a ser mais persistente, estão 
imunes: fazendeiros mexicanos no Sudoeste, pescadores vietnamitas na Costa do Golfo, médicos iranianos no Centroeste americano.

Eu não preciso continuar a multiplicar exemplos. Você todos podem pensar os seus a partir de suas próprias transações com o seu próprio meio. Nem toda esta diversidade é igualmente consequente (a cozinha jogja sobreviverá deliciosa como sempre); igualmente imediata (você não precisa conhecer as convicções religiosas do homem que lhe vende selos); nem brota toda ela de um tipo bem definido de contraste cultural. Mas que o mundo está ficando em todos os lugares mais parecido com um bazar kuaitiano do que com um clube de gentlemen inglês (para dar o que, para mim - talvez porque nunca estive em nenhum deles - são os casos extremos) parece tremendamente claro. $\mathrm{O}$ etnocentrismo, seja do tipo ovos de piolho ou do tipo poderia-ser-eu-se-tivesse-nascido-lá pode ser ou pode não ser coincidente com a espécie humana; mas agora é bem difícil para a maioria de nós saber aonde, na grande montagem de diferenças justapostas, centralizá-lo. Les milieux são todos mixtes. Eles não fazem mais Umwelre como antigamente.

Nossa resposta a este fato determinante é um dos principais desafios morais que hoje em dia defrontamos e integra virtualmente todos os demais desafios, desde o desarmamento nuclear até a distribuição mais justa dos recursos do planeta, e ao enfrentá-lo, os conselhos de tolerância indiscriminada, que em todo caso não são sinceros, e, meu alvo aqui, os de rendição orgulhosa, alegre, defensiva, ou resignada aos prazeres da comparação insidiosa são para nós igualmente maus; embora o último seja talvez o mais perigoso pela maior probabilidade de ser abraçado. A imagem de um mundo cheio de pessoas tão apaixonadamente apreciativas das culturas das outras que tudo o que desejam é festejar umas às outras não me parece um perigo claro e iminente; a imagem de um mundo cheio de gente glorificando alegremente os seus heróis e diabolizando os seus inimigos, isto sim, me parece um perigo. Não é necessário escolher, na verdade é necessário não escolher, entre o cosmopolitanismo sem substância e o paroquialismo sem lágrimas. Nenhum deles serve para se viver numa colagem.

Para se viver numa colagem é preciso em primeiro lugar tornar-se capaz de separar os seus elementos, determinando o que são (o que implica geralmente em determinar de onde vêm e o que valiam quando estavam lá) e como, 
na prática, eles se relacionam um com o outro, sem que ao mesmo tempo se embace o próprio sentido de localização e de identidade própria do indivíduo dentro dela. Menos figurativamente, "compreender" no sentido de compreensão, percepção, e intuição precisa ser diferenciado de "compreender" no sentido de concordância de opinião, união de sentimento, ou comunhão de comprometimento; o je vous ai compris que De Gaulle pronunciou e o je vous ai compris que os pieds noirs ouviram. Precisamos aprender a apreender o que não podemos abraçar.

A dificuldade nisso é enorme, e sempre foi. Compreender aquilo que é, e provavelmente continuará sendo, de alguma forma, estrangeiro para nós, sem suavizá-lo com vagos murmúrios de humanidade comum, desarmá-lo com a indiferença tipo cada-macaco-no-seu-galho, ou descartá-lo como lindo, adorável, mas inconsequente, é uma habilidade que temos de aprender a duras penas, e uma vez aprendida, imperfeitamente como sempre, temos de trabalhar sem cessar para mantê-la viva; não se trata de uma capacidade conatural, como a percepção de relações espaciais ou o senso de equilíbrio, da qual podemos depender com complacência.

É aí, no fortalecimento do poder de nossas imaginações para entender o que está na nossa frente, que se encontram os usos da diversidade, e do estudo da diversidade. Se temos (como eu admito ter) mais do que uma simpatia sentimental por aquele obstinado índio americano, não é porque comungamos com os seus pontos de vista. O alcoolismo é um mal verdadeiro, e em suas vítimas os aparelhos de diálise são mal empregados. Nossa simpatia vem do nosso conhecimento de até que ponto ele conquistou o direito aos seus pontos de vista e a amargura que portanto há neles, da nossa compreensão do terrível caminho que ele teve de percorrer para chegar a eles e o que - o etnocentrismo e os crimes que ele legitima - tomou-o tão terrível. Se quisermos ter a capacidade de julgar, como devemos querer, precisamos nos tornar capazes de ver. E para tanto, o que já vimos - as entranhas das nossas cabines de trem; os exemplos históricos iluminadores de nossas nações, nossas igrejas, e nossos movimentos - por mais fascinante que seja um e por mais ofuscante que seja o outro, simplesmente não basta.

(Traduzido do inglês por José Fonseca) 


\section{Referências}

DANTO, A. Mind as feeling; form as presence; Langer as philosopher. Journal of Philosophy, n. 81, p. 641-647, 1984.

LÉVI-STRAUSS, C. O olhar distanciado. Lisboa: Edições 70, 1986.

RORTY, R. Postmodernist Bourgeois Liberalism. Journal of Philosophy, n. 80 , p. $583-589,1983$.

RORTY, R. Liberalismo burguês pós-moderno. In: RORTY, R. Objetivismo, relativismo e verdade. Rio de Janeiro: Relume Dumará, 1997. 